\title{
THE PRESIDENCY, WAR, AND FOREIGN AFFAIRS: PRACTICE UNDER THE FRAMERS*
}

\author{
Abraham D. Sofaer $\dagger$
}

\section{INTRODUCTION}

American government is in a period of turmoil and apparent change. Our nation's recent failures, diplomatic and military, foreign and domestic, have undermined confidence in existing institutions and practices. The executive branch, in particular, is blamed for much of what has gone wrong. Recent presidents are said to have exercised too much power over all forms of legislation, controlled information to prevent criticism or legislative interference, engaged in covert activities here and abroad, and made war without sufficiently explicit legislative approval.

Congress has adopted unprecedented measures to check sweeping executive claims of power over foreign and military affairs. Most notable is the War Powers Act. ${ }^{1}$ Other measures have been considered, including proposals to submit to the courts some conflicts between the legislative and executive over access to information. ${ }^{2}$ The courts have been busy deciding cases concerning the division of powers, even without special legislative encouragement. ${ }^{3}$

\footnotetext{
* This paper is based on research conducted by Professor Sofaer as Director of the American Bar Association sponsored study of the war powers in American history. The views expressed are the sole responsibility of the author. For greater detail and discussion of the incidents described herein, see A. Sofaer. War, Foreigx Affairs and Coxstitutional Power: The Origins (1976).

$\dagger$ Professor of Law, Columbia Universitv.

1. Joint Resolution of Nov. 7, 1973, Pub. L. No. 93-148, 87 Stat. 555. Other notable examples are the Congressional Budget and Impoundment Control Act of July 12, 1974, Pub. L. No. 93-344, 88 Stat. 297 (codified in scattered sections of 1. 2, 31 U.S.C.); and the Antideficiency Act of 1950 , ch. $896, \S 3679 \mathrm{c}(2), 64$ Stat. 765 , as amended, 31 U.S.C. $\$ 665$ (Supp. IV, 1974). The executive's authority to impound under this statute has been strictly construed. State Highway Commin v. Volpe, 479 F.2d 1099, 1118 (8th Cir. 1973).

2. See S. 2073, 93d Cong., 1st Sess. (1973). This bill has not been reintroduced.

3. The most striking example is United States v. Nixon, 418 U.S. 638 (1974), in which a unanimous Supreme Court refused to allow the President to decide unilaterally what information to submit in response to a judicial subpoena. Title III of the Omnibus Crime Control and Safe Streets Act of 1968, 18 U.S.C. $\$ \$ 2510-20(1970)$, has also provided bases for litigation. See, e.g., United States v. Giordano, 416 U.S. 505 (1974); United States v. Chavez, 416 U.S. 562 (1974). More recently, telephone surveillance of executive department officials by the Secretary of State has been the subject of a civil action. See Halperin v. Kissinger, 401 F. Supp. 272 (D.D.C. 1975); N.Y. Times, Jan. 13, 1976, at 21, col. 2. The issue of impoundment of funds appropriated by Congress has also stimulated court activity. See Train v. New York, 420 U.S. 35 (1975) (Impoundment Control Act does not permit allotment of less than entire amounts authorized to be appropriated). See also, on the impoundment issue, e.g., Pennsylvania v. Lynn, 501 F.2d 848 (D.C. Cir. 1974); Pennsylvania v. Weinberger, 367 F. Supp. 1378 (D.D.C. 1973). The Vietnam
} 
This symposium is an attempt to focus on the present state of executive power and to consider remedies for felt deficiencies or dangers. The symposium understandably enlists people from many different fields and with a broad spectrum of views on the crucial issues. They must all, to one degree or another, invoke and rely upon past experience as a guide, just as Congress and the courts use experience to devise or at least to rationalize proposed solutions. Indeed, many politicians and writers, since the war in Vietnam, have used history to explain or to justify what went wrong and to devise new rules or institutions to deal with the problem of distributing power between the executive and legislative branches.

The purpose of this paper is to deal with one recurrent use of history in the current debate over our institutions of government. Again and again, those critical of recent practices have invoked the experience of the Constitution's framers. ${ }^{4}$ The first twenty to thirty years of experience under the present Constitution are generally regarded as a period of national progress and achievement, and modern critics strongly suggest that our early successes may be attributed, at least in part, to the willingness of our first presidents to abide by the Constitution. ${ }^{5}$

An important example of this use of our early history is found in the Report of the Senate Committee on Foreign Relations, filed February 9, 1972,

War engendered a flurry of activity in the courts. Holtzman v. Schlesinger, 484 F.2d 1307 (2d Cir. 1973), cert. denied, 416 U.S. 936 (1974) (reversing district court decision that there was not sufficient authorization to warrant Cambodia bombings, on ground that issue presented a political question); Da Costa v. Laird, 471 F.2d 1146 (2d Cir. 1973) (repeal of Tonkin Resolution did not withdraw congressional authorization implicit in other legislation); Orlando v. Laird, 443 F.2d 1039 (2d Cir.), cert. denied, 404 U.S. 869 (1971) (Gulf of Tonkin Resolution held sufficient authorization).

4. See, e.g., Senate Comm. on Foreigi Relations, 91 st Cong., 2d Sess., Documents Relating to the War Power of Congress, The President's Authority as Commander-in-Chief and THE WAR IN INDOChINa 12-13, 74-76, 88, 99-101, 153-56 (Comm. Print 1970); Hearings on War Powers Before the Subcomm. on National Security Policy and Scientific Developments of the House Comm. on Foreign Affairs, 93d Cong., 1st Sess. 31 (Thomas F. Eagleton), 209-12 (Raoul Berger) (1973); Hearings on Congress, the President, and the War Powers Before the Subcomm. on National Security Policy and Scientific Developments of the House Comm. on Foreign Affairs, 91st Cong., 2d Sess. $513-17$ (1970) (Harvard Law Review Legal Memorandum on the Constitutionality of the Amendment to End the War); R. Berger. Executive Privilege: A Constitutional MYth 78-81, 130-40, $167-81$ (early practice), 11-14, 35-42, 50-56, 61-69, 127-29, 146-49 (original intent) (1974); Ratner, The Coordinated Warmaking Power-Legislative, Executive, and Judicial Roles, 44 S. CALIf. L. REv. 461, 464 n. 12, 470 (1971): Revelev, Presidential War-Making: Constitutional Prerogative or Usurpation?, 55 VA. L. Rev. 1243, 1260-61 (1969); Van Alstyne, Congress, the President, and the Power to Declare War: $A$ Requiem for Vietnam, 121 U. PA. L. REv. 1, 7-11 (1972).

Those defending recent practices have also frequently invoked the framers' experiences to support their arguments. See, e.g., Rogers, Congress, the President and the War Powers, 59 Calif. L. Rev, 1194-98 (1971); Documents Relating to the War Power of Congress, supra at 176; Hearings on War Powers, supra at 297 (Barry Goldwater). Edward Corwin raised many of these arguments over half a century ago. See E. Corwin, The President's Control of Foreign Relations 90-97, 131-35 (1917).

5. See Documents Relating to THE War Power of Congress, supra note 4, at 30-31; Hearings on War Pouers, supra note 4, at 31-32 (statement of Thomas F. Eagleton). 
concerning an early version of the "war powers bill." The report flatly asserts that "whatever else they may have painted with a 'broad brush,' the Framers of the American Constitution were neither uncertain nor ambiguous about where they wished to rest the authority to initiate war," namely "in the legislature, and in the legislature alone." 6 The power to declare war and to control the military resources placed at the nation's disposal are repeatedly cited as reflecting an intent to require legislative approval before war is commenced. Some commentators even argue that the Constitution meant to avoid the sort of gradual involvement that occurred in Vietnam by requiring Congress to declare war or to authorize it unequivocally, not just to delegate vague discretionary power over military actions or to pay for actions already undertaken. ${ }^{7}$ Treaties committing the nation to come to the aid of others represent, under this view, only a prediction by the President and Senate that the Congress would, when faced with a situation contemplated in the treaty, authorize hostilities in the constitutionally prescribed manner. The sole exception to the requirement of prior legislative approval, some assert, is the President's power to defend the nation from actual, or perhaps also imminent, attack. ${ }^{8}$ And this power is sometimes narrowly construed to limit its application to attacks on the nation as a geographic entity, rather than on ships and citizens abroad, and to preclude preemptive strikes.

The unambiguous allocation allegedly made by the framers was, according to the theory I am addressing, faithfully followed by the same men when they assumed power. No in-depth exposition of what actually occurred in the early administrations is attempted to demonstrate this hypothesis. Rather, isolated and-as I will show-unrepresentative and misleading events are relied upon, such as Madison's argument in the Pacificus-Helvidius debate, Jefferson's statement in his first annual address that Congress alone has the power to authorize "offensive" military actions, and Madison's message of June 1, 1812 , asking Congress whether the United States should go to war with Britain-"a

6. Senate Comm. on Foreign Relations, War Powers, S. Rep. No. 606, 92d Cong., 2d Sess. 12 (1972).

7. See, e.g., ACLU Amicus Brief and Appellant's Brief, Orlando v. Laird, excerpted in L. Friedman \& B. Neuborne, Unquestioning Obedience to the President, The aclu Case Against the Illegal War in Viet Nam 62-72, 130-74 (1972); Van Alstyne, supra note 4, at 16-17; Velvel, The War in Vietnam: Unconstitutional, Justiciable and Jurisdictionally Attackable, in 2 The Vietnam War and International Law 65l, 680-81 (R. Falk ed. 1969); $c f$. Bickel, Congress, the President and the Power to Wage War, 48 Chr.-Kent L. Rev. 131 , 137 (1971).

In Orlando v. Laird, 443 F.2d 1039 (2d Cir.), cert. denied, 404 U.S. 869 (1971), the court held the Gulf of Tonkin Resolution and other legislative collaborations to be sufficient authorization for the war. Even after the Gulf of Tonkin Resolution was repealed, the Second Circuit found adequate authorization. See Da Costa v. Laird, 448 F.2d 1368 (2d Cir. 1971), cert. denied, 405 U.S. 969 (1972). See also Da Costa v. Laird, 471 F.2d 1146 (2d Cir. 1973).

8. See, e.g., statement of Professor Richard B. Morris, in S. REP. No. 606, supra note 6, at 15; Bestor, Separation of Powers in the Domain of Foreign Affairs: The Original Intent of the Constitution Historically Examined, 5 Seton Hall L. Rev. 529, 612 (1974); Reveley, supra note 4, at 1285-88, 1290 n.55. 
solemn question which the Constitution wisely confides to the legislative department of the Government."

Much can be gained, I think, by reviewing the highlights of our early history to determine how the framers and their contemporaries actually viewed and exercised power. Enough has been said to establish that the constitutional allocation of powers relating to war making is far from unambiguous. ${ }^{10}$ Clearly, the Constitution accords Congress the upper hand, or final say, on most issues of significance. But it also assigns the President great powers over the military, and in the execution of policy. What needs closer examination than it has so far received is the construction actually given the Constitution's allocation during the first few administrations.

Forging the Executive Branch, 1789-1797

Any in-depth treatment of the allocation of power over foreign and military affairs in modern times necessarily leads to a discussion of the extent to which the American executive controls other powers and functions that virtually assure him the power to make war or to lead the nation to war. The presidency gains its war-making capacity not only from the power to command the military forces Congress provides but from its control of the conduct of foreign relations, including its capacity to obtain and to keep from Congress information necessary for that body to formulate and to judge foreign and military policy; from its extensive role in planning legislation, including the budget; from the discretion it exercises over funds allocated by the legislature; from its control over most important executive offices; and perhaps most of all from the vast powers Congress has willingly delegated that directly concern the use of military force.

The first lesson of George Washington's presidency is that the pattern of executive-congressional relations that we associate with the modern executive was established in all its essentials by 1797. This was accomplished, moreover, with a remarkably high degree of awareness in the legislature of the enormous power that the executive might acquire if allowed to assume the functions involved. One of the first decisions made by Congress, for example, was to allow, or to recognize, the President's power to remove the principle execu-

9. Madison's papers as Helvidius are in 6 The Writisgs of James Madisox 138-88 (G. Hunt ed. 1906). Jefferson's statement is in 11 Axxals of CoxG. 11, 12 (1801); and Madison's message is in 24 Annals of Cong. 1714,1719 (1812).

10. The best and most balanced treatment is L. Henkin, Foreign Affairs and The Constitution (1972). Other able treatments include Bestor, supra note 8, at 537-66; Lofgren, War-Making Under the Constitution, The Original Understanding, 81 YALE L.J. 672 (1972); Reveley, Constitutional Allocation of the War Powers Between the President and Congress: 1787-1788, 15 VA. J. INT'L L. 73 (1974); Note, 81 HaRv. L. Rev. 1771, 1772-80 (1968). My own coverage is in A. SofaER, War, Foreigi Affairs and Constituminal Power: The Origins ch. 1 (1976). I 
tive officers without cause. Many of those favoring this allocation rested their case on an expansive construction of the power to execute the laws. As Madison described the prevailing argument: "[T] $[\mathrm{T}$ e Executive power being in general terms vested in the President, all power of an Executive nature not particularly taken away must belong to that department." 11 The planning function was quickly assumed by Washington, who ordered Secretary of War Henry Knox to prepare a plan for organizing the militia; ${ }^{12}$ Congress seemed agreeable to this mode of proceeding when it included in the act establishing the Treasury a requirement that the Secretary "digest and prepare plans" concerning revenue and expenditures, ${ }^{13}$ and soon thereafter instructed Alexander Hamilton to report a plan for supporting the public credit. ${ }^{14}$ Republicans forcefully challenged this practice when they increased their numbers in the Second Congress, warning "that the Executive, or rather the Treasury Department, was really the efficient Legislature of the country, so far as relates to the revenue, which is the vital principle of Government." ${ }^{15}$ But rather than restricted, the practice was actually expanded to include planning for frontier defense, with many legislators noting the superior capacity of executive officers to prepare plans in their respective areas of expertise. ${ }^{16}$

Congress quickly granted the executive broad control over funds by making most appropriations in lump sums; by allowing the Secretaries of Treasury and War to shift such funds as were specifically appropriated from one category to another; by appropriating funds to cover deficiencies in categories for which appropriations had been expended; and by ratifying expenditures on authorized purposes for which no appropriation had been made, such as the expedition to suppress the so-called Whiskey Rebellion. ${ }^{17}$ Albert Gallatin's opposition to these practices was as sophisticated and effective as any that could be mounted today, after almost two hundred years of experience. ${ }^{18} \mathrm{But}$

11. Letter from James Madison to Edmund Pendleton (June 21, 1789), in 5 WRitings of James Madison 405-06 (G. Hunt ed. 1904). Madison noted that this doctrine was subject to modification but that he favored executive authority over removal to help preserve an equilibrium against the far more awesome legislative power.

12. See 1 Annals of Cong. 938 (1790). See also 2 Annals of Cong. 2087-2107 (1790).

13. Act of Sept. 2, 1789, ch. 12, $\$ 7,1$ Stat. 65. For the related debate, see 1 Anvals or Cong. $615-31(1789)$.

14. See 1 Anivals of Cong. 904 (1789).

15. 3 Anvals of Covg. 351 (1792).

16. See particularly the statement of Theodore Sedgwick, of Massachusets, id, at 437-40, including his response to Madison's contentions. A comprehensive statement by John Page. of Virginia, against such delegations appears in id. at 441-44. Military planning was added to the list of executive functions in 1795. See 4 ANwals of CoNc. 1120-21 (1795).

17. See generally L. White. The Federalists, A Stldoy is Admisistrative History 326-29 (1961); L. Wilmerding. The Spending Power, A History of the Efforts of Congress to Control Expenditures 20-49 (1943). The Act of Dec. 31. 1794, ch. 6. 1 Stat. 404, appropriated funds to cover expenses incurred in suppressing the insurrection.

18. For a sampling of Gallatin's arguments, see 6 ANwals of CoNG. 2336-42. 2348-51, 2358 $(1797)$ 
his minor successes proved futile in practice and were undone before Washington's second term ended. ${ }^{19}$

Just as Congress allowed the executive broad fiscal discretion, it delegated broad, undefined authority over foreign and military affairs. ${ }^{20}$ Legislators recognized that to delegate without specificity on subjects like the suppression of insurrections was both dangerous and an abdication of Congress' duty. ${ }^{21}$ But the only subject on which Congress consistently insisted on specificity was the location of post roads, ${ }^{22}$ which of course involved the allocation of contracts for construction, maintenance, and related economic development.

Washington early decided, after cabinet discussion, that he possessed discretion to withhold information requested by Congress if its disclosure might harm the nation's interests. ${ }^{23}$ He actually exercised this power on two occasions-once in response to an unqualified Senate request for certain dispatches from the minister to France, Gouverneur Morris, and once in response to a House request for material relating to the Jay Treaty. ${ }^{24}$ In the second instance, he went so far as to assert that the House lacked power to consider the merits of treaties duly ratified by the Senate, a position the House majority resolved to reject. ${ }^{25}$ Neither the House nor the Senate, how-

19. Gallatin succeeded in having included in the military appropriations for 1797 language to the effect that sums specified "shall be solely applied to the objects for which they are respectively appropriated." 6 ANNals of CoNG. 2349 (1797). The change was ineffectual in controlling military spending, and was rejected the very next year. See 7 Ansals of Cong. 575; 8 Annals of CoNG. 1874 (1798): L. WilMerding, supra note 17, at 44-45.

20. For example, on June 5,1794 , Washington was authorized to use land and naval forces to keep foreign cruisers fitted out here in the United States from carrying on hostile action against a state with whom this country was at peace, and to make foreign vessels depart when by the law of nations or United States treaties they ought not to remain. Act of June 5, 1794, ch. 50, 1 Stat. 384. In the Resolution of March 26, 1794, I Stat. 400, Congress authorized the President to administer and enforce an embargo in the manner best adopted to give it "full effect." Most significantly, in the Act of June 4, 1794, ch. 44, I Stat. 372, the President was given virtually complete discretion, during the recess of Congress plus fifteen days, as to whether and when to lay an embargo. the vessels to be covered, and the regulations to be adopted in its implementation. The Act of Sept. 29, 1789. ch. 25, I Stat. 95, 96, granted the President authority "to call into service from time to time, such part of the militia . . . as he may judge necessary" to protect the inhabitants of the frontiers from hostile incursions by Indians. Section 1 of the Act of May 9 , 1794, ch. 27. I Stat. 367, authorized the President to require the states to have 80,000 effective militia held "in readiness to march at a moments warning." Discretion as to whether to build up to a certain number of naval vessels was delegated in Act of March 27, 1794, ch. 12, 1 Stat. 350 and Act of June 5, 1794, ch. 46, I Stat. 376.

21. See 3 Anvals of Cong. $552-55$ (1792) (debate on militia bill). Some legislators urged greater specificity even for subjects of lesser importance. See, e.g. I ANisals of CoNc. 879-80 (1789) (debate about permanent seat of government).

22. See 2 ANNals of Cong. 1527, 1640-41, 1676-77, 2295 (1790); 4 ANwals of CoNg. $1431-43$ (1794); 6 ANNals of Cong. 2957 (1797).

23. See The Complete Jefferson 1222-23 (S. Padover ed. 1943); Sofaer. Book Retifu. 88 HARV. L. REv. 281, 289-90 (1974).

24. For a summary of these instances, see Sofaer, Executize Prizilege: An Historical Note, 75 Colum. L. Rev. 1318-21 (1975).

25. See 5 Anvals of Cong. $771-72,782-83$ (1796). 
ever, challenged his claim that he could withhold information "for public considerations." 26

The second major lesson of Washington's administration was that he assumed the power to make unilateral decisions in foreign affairs that could have led to war. The Neutrality Proclamation of 1793 was not the first time Washington and his cabinet decided that they could declare the nation's policy; they were ready to do so in 1790, during the Nootka Sound controversy. ${ }^{27}$ What the cabinet added in 1793 was its unanimous decision to dispense with calling Congress into special session. ${ }^{28}$ Washington decided to construe treaties to avoid apparent obligations to France, and to promulgate and enforce regulations against American assistance to either the French or British. His decision to delay consulting Congress until months after implementing these policies was undoubtedly based on his apprehension, shared even by Jefferson, that Congress might too readily be swayed by popular support for France. ${ }^{29}$ While these decisions were being made and executed, Hamilton and Madison engaged in a written debate as Pacificus and Helvidius. Madison insisted that the President could not exercise even a specifically assigned power without calling Congress if its exercise could make war more likely. ${ }^{30}$ This position, repeated as authority even today, ${ }^{31}$ was rejected in practice by Washington and his entire cabinet, including Jefferson; and when Congress convened, it overwhelmingly approved what Washington had done. $^{32}$

26. See 4 ANNals of CoNg. 56 (1794). An interesting contrast in this regard is Washington's willingness to reveal all information demanded by Edmund Randolph in the personal dispute that resulted from Randolph's dismissal from the cabinet. See J. Flexner, George Washington: ANGuish and Farewell 234-39 (1972).

27. See 17 The Papers of Thomas Jefferson 109-10 (J. Boyd ed. 1965). See also id. at 121 , $127,128-29,135-36,138-39,141-42 ; 18$ id. at 289-93; 4 The Works of Alexander Hamilton 53 (J. Hamilton ed. 1850).

28. Washington asked his cabinet whether Congress should be called back early, and they voted against doing so. See 12 Writings of George Washington 280-81 (W. Ford ed. 1891); 6 Writings of Thomas JefFerson 219 (P. Ford ed. 1895).

29. See Letter from Thomas Jefferson to James Madison (June 2, 1793), in Writixgs of Thomas Jefferson, supra note 28, at 277, 278-79. Two months later, on August 4, 1793, Jefferson did argue that Congress should be convened earlier than scheduled. But he sought only a starting day in early November, instead of the scheduled opening in December. "because while it would gain a month in making provisions to prevent or prepare for war, it leaves such a space of time for their assembling, as will avoid alarm either at home or abroad." Id. at 363. By that time, the President's policies had been formulated and largely implemented. See generally C. Thomas, American Neutrality in 1793, A Study in Cabinet Government (1931).

30. See 6 Writings of James Madison 170-71, 182-83 (G. Hunt ed. 1906).

31. See, e.g., Berger, The Presidential Monopoly of Foreign Relations, $71 \mathrm{MrCH}$. L. Rev. 1, 17-25 (1972) (attempting to refute Hamilton's Pacificus position of a plenary executive power and supporting generally Madison's Helvidius position); Note, 81 HaRv. L. Rev. 1771, 1786-87 (1968) (referring to any deployment of troops by the executive).

32. See 4 Annals of Conc. $17-18$ (1793) (Senate); id. at 138-39 (House). 


\section{Undeclared War as Conscious National Policy}

John Adams was a Federalist. As such, he was committed to the pattern of executive-congressional relations established during Washington's tenure. On the other hand, Adams lacked Washington's political strength. He faced a hostile Congress throughout his term as President, dominated by Republicans, who in general favored France over Britain. Consequently, when France persisted in seizing American commerce, Adams realized that he would have grave difficulty obtaining a declaration of war.

He specifically asked his cabinet in early 1798 whether he should seek a declaration. Secretary of War James McHenry replied on February 15, after being tutored by Hamilton, by then practicing law in New York. ${ }^{33}$ The people were generally averse to war, he said, and a portion of them particularly averse to war with France. He recommended, instead, an undeclared war as the national policy: ${ }^{34}$

An express declaration of hostility . . would subject us to ... all the chances of evil which can accrue from the vengeance of a nation stimulated by . . . extraordinary success ... [a] mitigated hostility will [therefore] be the most likely to fall in with the general feeling, while it leaves a door open for negotiation and secures some chance to avoid some of the extremities of a formal war.

Soon thereafter, Adams received firm evidence, in the so-called XYZ Papers, that the ministers he had sent to France had been poorly treated and asked to pay bribes. Once again, he asked his cabinet whether to recommend "an immediate declaration of war." ${ }^{35}$ At least one member urged such a recommendation, ${ }^{36}$ but McHenry persisted in his view that a "qualified hostility" was preferable to a formal declaration of war, since France had qualified its hostility and had held out 'terms of accomodation, tho' humiliating and inadmissible in their present nature and form. . . Such a procedure as this, while it secures the objects essential and preparatory to a state of open war, involves in it the fewest evils, and the greatest number of possible chances and advan-

33. See The Life and Correspondence of James McHenry 291-95 (B. Steiner ed. 1907). Hamilton replied in a detailed paper to McHenry's request of January 26 that Hamilton assist him with "suggestions and opinions," since a "wrong policy" could be "extremely injurious," and he, McHenry, could not "do justice to the subject," as Hamilton could. Id. at 29l. McHenry's answer practically embodied the whole of Hamilton's letters. See Adams Papers, Mass. Hist. Soc'y microfilm, pt. IV, reel 387, item 267.

34. Adams Papers, supra note 33.

35. 8 WORKS OF JOHN ADAMS 568 (C. Adams ed. 1856).

36. See Letter from Charles Lee to John Adams (Mar. 14, 1798), in Adams PAPERs, supra note 33 pt. IV, reel 387, item 218. 
tages." He advised that Congress be asked to set aside existing treaties with France, and to provide the means for defense. ${ }^{37}$

Adams accepted McHenry's advice. The President announced to Congress on March 19, 1798, that he had studied the dispatches and concluded there was no ground to expect peace. He called again for defensive preparations and unilaterally suspended the order he had issued restricting the arming of merchant vessels. But he did not request a declaration of war. ${ }^{38}$

Republicans in Congress sensed the nation's drift toward war and began to press for a definitive legislative determination of the question, hoping thereby to avert the conflict. A resolution was proposed declaring it inexpedient "to resort to war" with France. ${ }^{39}$ Any chance that the resolution might pass was destroyed, however, after Republicans successfully pressed Adams to reveal the XYZ Papers. These dispatches shifted sentiment sharply against France, and Congress proceeded to grant Adams the means and authority he sought without a formal declaration. ${ }^{4 \prime}$

Even as the war raged, the case of Bas $\because$ Tingy reached the Supreme Court, and the Justices unanimously made known their view that "imperfect" war, as they called it, was constitutionally permissible. ${ }^{41}$ The Court held that the Act of March 2, 1799, which authorized an award of one-half the value of any American vessel seized from an "enemy," was applicable to a seizure from a French privateer, even though Congress had not declared war. France was an "enemy," ruled the Court, because war existed in fact and because Congress had France in mind when it passed the law in question. War did not come in just one variety, wrote Justice Bushrod Washington: "[E]very contention by force, between two nations, in external matters, under the authority of their respective governments, is not only war, but public war." 42

Instead of perceiving danger in allowing Congress to authorize military action without the public acquiescence that would usually be necessary to engineer a declaration, Justice Chase praised Congress for proceeding piecemeal in the face of public opposition: ${ }^{43}$

The acts of congress have been analyzed, to show. that a war is not openly denounced against France, and that France is nowhere expressly called the enemy of America: but this only proves the circumspection and prudence of the legislature. Considering our national prepossessions in favor of the French republic, congress had an arduous task to perform, even in preparing for necessary defence and just retaliation. As the temper of the people rose. however, in resentment of accumulated wrongs, the language and the mea-

37. See Letter from James McHenry to John Adams (Mar. 14, 1798), in id, at reel 387, item 270.

38. Su 8 ANitals of CoNg. $1271-72$ (1798).

39. See id. at 1319 .

40. Ser the cluster of statutes in 1 Stat. $552-65$

41. 4 U.S. (4 Dall.) 37 ( 1800$)$

42. Id. at 40 .

43. Id. at 45 
sures of the government became more and more energetic and indignant; though hitherto the popular feeling may not have been ripe for a solemn declaration of war; and an active and powerful opposition in our public councils, has postponed, if not prevented, that decisive event, which many thought would have best suited the interest, as well as the honor, of the United States.

He even compared "the progress of our contest with France" with "the progress of our revolutionary contest; in which, watching the current of public sentiment, the patriots of that day proceeded, step by step," from supplication to "the bold and noble declaration of national independence." ${ }_{44}$

In conclusion, the Quasi War was undeclared by design. It was undeclared primarily because of the executive's need to avoid the risk of alienating a large segment of Congress and the American people. Congress eventually went along with the President, and the Supreme Court approved the constitutionality of "imperfect" war, stating that Congress could make war by degrees if it chose to do so.

\section{I}

\section{The Inglorious "Revolution of $1800 "$}

Thomas Jefferson hailed his victory over John Adams as the "Revolution of 1800." This dramatic phrase was used to symbolize the triumph of Republican over Federalist ideology.

In addition to advocating strict construction of all powers conferred upon the federal government and leaving matters other than foreign affairs to the states, Republicans called for a reallocation of power from the federal executive to Congress. They had objected, during the period of Federalist control, to executive planning and to statutes assigning broad powers to the President to conduct military and foreign affairs. They had battled for greater control of expenditures through specific appropriations. They had insisted on Congress' right to information in the President's control. Many of them had claimed that Congress should be consulted as soon as possible on issues relating to its specifically assigned powers, including the power to declare war. The election of 1800 swept these Republicans into control of the nation and therefore promised a major overhaul in the pattern of executive-congressional relations established under Washington and Adams.

Events during Jefferson's two terms clearly demonstrate that the allocation of power between Congress and the executive changed little, if at all, from the pattern established in the first two administrations. As Leonard White says in his excellent work, The Jeffersonians, "Jefferson fully maintained in practice the Federalist conception of the executive power." 45 In fact, it seems fair to

44. Id.

45. L. White, The Jeffersonians, A Study in Administrative History, 1801-1829, at 30 (1959). 
say that Jefferson's commitment to Republican doctrine may have been partly responsible for his adopting and advancing practices far more dangerous to the balance of power among the branches than conventional Federalist ideology.

Executive planning continued unabated. ${ }^{46}$ The House initiated an investigation of spending practices, but no attempt to reform those practices was made; deficit spending became a way of life for the armed services. ${ }^{47}$ Jefferson went further than his predecessors in this regard after the attack on the American frigate Chesapeake by the British warship Leopard. He ordered purchases of arms and ammunition even though Congress had neither approved such expenditures nor appropriated funds for the purpose. He considered, but decided against, calling Congress back into session, undoubtedly because he wished to avoid a legislative drive for immediate war against Britain. ${ }^{48}$ The similarity to Washington's failure to call a special session in 1793 is apparent. Jefferson added a new element, however. Rather than attempting to legitimize his orders under the Constitution, he justified the purchases on the ground of emergency, trusting in the legislature to condone his conduct. Congress overwhelmingly appropriated the funds to cover the purchases, some noting, in effect, that "the safety of the nation is the supreme law."49 John Randolph sought to remind his Republican colleagues that Jefferson should have called Congress into session while "they would have felt a deep and particular sense of national indignity," ${ }^{\prime \prime}$ but others condoned Jefferson's postponing the meeting "till the fermentation should have subsided." 51

Broad delegations continued to be made, causing Republican Representative Richard Stanford, of North Carolina, to "ask how it will be possible, in a

46. On December 22, 1801, for example, John Randolph moved that the House direct the Secretary of War to prepare a statement of the present military establishment, along with an estimate of necessary posts and men for each garrison. The House agreed without opposition. See 11 Axvals of Cong. 348-49 (1801). Similar motions had been intensely opposed during Washington's administration.

47. See generally L. Wilmerdisg, supra note 17, at 26; L. White, supra note 45, at 115-16. See also 11 Axwals of CoNg. 1285 (1802); 12 Axvals of CoNg. 290 (1802), after which the investigation lapsed.

48. See 17 Axwals of Cong. 14-18 (1807).

49. Id. at 848 (Gardenier). See also id. at 832 (Montgomery), 840 (Alston)

50. Id. at 830. Referring to Representative Montgomery's argument based on emergency, Randolph said: "The more he magnified the danger of the crisis, to justify an illegal and unconstitutional expenditure of the public money, the more clearly did he demonstrate the necessity for convening Congress." Id. at 837 .

51. Id. at 826 (Smilie). Smilie said he was more temperate than Randolph, and "alluded to an ancient nation, who were wont to discuss great national questions twice, once when they were drunk, that they might not want spirit, and once when they were sober, that they might not be deficient in prudence." He suggested that Jefferson's decision had saved them from being "under the immediate influence of passion." $I d$. at 830 . W. Alston concurred: "We are now better prepared to decide... and if by this prudent course war had been averted, the voice of the nation would approve it." Id. at 840. 
few years, for any political observer or historian to draw a line of distinction between parties."52 Jefferson's legislative leader, William Branch Giles, responded by citing precedents, many of which he and other Republicans had previously opposed, and observing that the line between executive and legislative power was impossible to fix. He described the delegation issue as "an old and abstract question, often heretofore brought into view, and leads to endless discussion." He was "unwilling to look into retrospection; it could only produce an unpleasant and unprofitable examination. . . . I would rather follow the example of a celebrated Roman conqueror. It was his maxim always to forget the last defeat, and to turn his whole thoughts upon the best means of obtaining victory in the next battle." ${ }^{53}$

Jefferson on several occasions indicated his belief that he could withhold information from Congress if its disclosure would harm the nation, ${ }^{54}$ but he never explicitly refused Congress material, except where the relevant request was qualified to allow withholding. ${ }^{5 \overline{5}} \mathrm{H}$ is behavior in this regard cannot, however, be attributed to any conviction on his part that Congress was entitled to all important information in his control. One reason he was able to avoid invoking some form of "executive privilege" was the enormous control he exercised over Congress through his party leadership. Motions to request information on sensitive or potentially embarrassing subjects were repeatedly voted down by the Republican majorities in both Houses. ${ }^{56}$ The other reason

52. 18 ANNals of Cong. 1946 (1808). Rep. Richard Stanford, of North Carolina, said: "It was once a fashion with us to object to that of giving the President discretion to raise, or not raise, an armv," Id. at 1950 .

53. 19 Anvals of Cong. 259 (1808).

54. For example, Jefferson wrote to William Giles that he regarded a resolution that would have requested his reasons for refitting the French vessel Berceat as improper, and said if a resolution "is passed on ground not legitimate, our duty will be to resist it." Letter from Thomas Jefferson to William Giles (Apr. 6, 1802), in 8 Writixgs of Thomas JefFerson, supra note 28, at 142. The House, on January 11, 1808, passed a request for material relating to whether any officer of the United States had received money from any foreign government, after Josiah Quincy unsuccessfully objected to the lack of a qualification allowing the President to withhold "confidential" correspondence. See 18 ANxals of Coxg. 1460 (1808). Jefferson responded on January 15 that "he would give to the House such information not improper to be disclosed." Id. at 1464. In responding to requests from both Houses of Congress for copies of all decrees and acts promulgated since $179 \mathrm{l}$ by the belligerent European powers affecting the commercial rights of the United States, Jefferson sent the decrees that could be obtained "and are supposed to have entered into the view's of" each House. 19 AxNals of CoNg. 299. 908 (1808). See also the several claims by Jefferson of power to withhold material from the court in the Burr conspiracy trial, discussed in Freund, Foreword: On Presidential Prizilege, 88 Harv. L. Rev. 13, 24 n.60 (1974), and authorities cited therein.

55. See, e.g., 15 ANwals of CoNG. 67-68, 70-71 (1806) (Senate motion requesting President to supply copy of letter from Monroe to Madison, amended January 21, 1806, to specify date and to qualify request for disclosure "if he shall judge the same to be proper"); id. at 71 (letter provided); 16 Ansals of Cong. 336 (1807) (House request for information relating to Burr conspiracy "in possession of the Executive, except such as he may deem the public welfare to require not to be disclosed"); id. at 39-43 (much information withheld).

56. See, e.g., 13 ANvals of Cong. 200-62 (1803) (Senate refusal to request information on measures taken by President pursuant to law authorizing military action. cost of same, and the 
he avoided confronting Congress with a claim of privilege was, simply stated, his readiness to withhold material without letting the legislature know of its existence. He established a system of dual correspondence that went far beyond anything his predecessors practiced, under which public, official communications were classified as "private" in order to keep them out of official files. ${ }^{57}$ He promised confidentiality to his informants and never materially breached the confidence they placed in him. ${ }^{58}$ When subpoenaed during the trials of Aaron Burr, he not only sought to invoke a discretion to withhold information, he also secretly withheld material potentially useful to Burr without even informing his own lawyers of its existence. ${ }^{59}$

further legislation necessary to end war with Tripoli): id. at $385-419$ (House refusal to request copies of treaties between France and Spain, and avaitable correspondence, tending to determine whether France had acquired title to Louisiana).

57. Soon after taking office, Jefferson sent the American Minister in France. Robert $R$. Livingston, a code for deciphering future messages. Why a cipher between us, asked Jefferson rhetorically, since official things go naturally to the Secretary of State and things not political need no cipher: Because, Jefferson explained, information falls into three categories:

1. [M]atters of a public nature, and proper to go on our records, should go to the secretary of state. 2. [M]atters of a public nature not proper to be placed on our records may still go to the secretary of state, headed by the word "private." But 3. there may be matters merely personal to ourselves, and which require the cover of a cipher more than those of any other character. [This latter category,] and others which we cannot foresee may render it convenient and advantageous to have at hand a mask for whatever may need it.

This letter of April 18, 1802, was apparenty one for which the cipher would normally be used: but "writing by Mr. Dupont I need no cipher," Jefferson said. Letter from Thomas Jefferson to Robert Livingston (Apr. 18, 1802), in 8 WRITINGS OF ThOMAS JEFFERSON, supra note 28, at 143-45.

The categories outlined by Jefferson in this extraordinary letter are susceptible to his labels of "public," "private," and "personal" only if the words are deprived of ordinary meaning. The letter itself makes clear that some matters of a "public nature" should be marked "private" and kept out of "our records." And in calling matter in the third category "merely personal," Jefferson seems clearly to have been referring to the fact that he wanted such information kept strictly between Livingston and himself, rather than attempting to describe the nature of the information in the letters. The April 18 letter most assuredly dealt with "public" rather than "personal" matters. It noted that Madison had written fully to Livingston concerning the question of Louisiana. but continued that Jefferson could not "forbear recurring to it personally." He told Livingston -in a now famous phrase-that the nation that holds New Orleans is "our natural and habitual enemy," and if France takes possession, it might force the United States to ally with Britain. This prediction of war, meant to guide Livingston, was certainly not "personal" in the ordinary sense. It was an official letter, about an important public matter. that Jefferson wanted kept secret.

58. For example, in a letter to Joseph Daveiss, the federal attorney for Kentucky, on February 15, 1806, Jefferson requested additional information concerning Aaron Burr's alleged activities and promised to keep such communications secret, at least until arrest became necessary, and even then Jefferson pledged to withhold the source of his information. See 10 THE WRITixas of Thomas JefFerson 231-32 (Fed. ed. 1904).

59. Chief Justice John Marshall issued a subpoena on June 13, 1807, at Burr's request, calling upon Jefferson and others to submit a letter from General James Wilkinson to Jefferson, dated October 21, 1806, to which Jefferson had referred in his message to Congress of January 22, 1807. See 16 Annals of Cong. 39-43 (1807). A major dispute erupted over Jefferson's obligation to produce the letter explicitly described in the subpoena, which has been widely discussed. The subpoena also called, however, for "the documents accompanving the same letter," as well as any reply. Subpoena duces tecum In re United States v. Aaron Burr (E.D. Va.) (kindly' supplied to the author, and on file with, Professor Dumas Malone, Alderman Library, University of Virginia). 
Jefferson's most important military involvements concerned the so-called Barbary States. Repeated seizures of American commerce by the pirates of Tripoli, Morocco, and other Mediterranean powers led Jefferson to follow Adams' example by dispatching a squadron of public vessels to the area. Anticipating that one or more of these nations might declare or make war upon Americans, Jefferson asked his cabinet what form of instructions he should issue to the squadron's commander, Richard Dale. The cabinet almost unanimously agreed that, if war was either declared or made upon Americans, Dale could be permitted to act offensively against the nation that had declared or made war. ${ }^{6 \prime}$ Instructions were issued authorizing Dale to sink, burn, capture, or destroy vessels attacking Americans, ${ }^{61}$ and Dale ordered the commanding officers in his squadron to act accordingly. ${ }^{\text {i: }}$

The specific orders Dale issued to one of his officers, Lieutenant Andrew Sterret, have taken on special historical significance. Sterrett commanded the Enterprise, a twelve-gun schooner that acted as tender vessel to Dale's squadron. Sterrett was told on July 30, 1801, after Tripoli had declared war, to sail to Malta from nearby Tripoli to obtain water. Dale knew Sterrett might meet and engage Tripolitan vessels. He therefore issued instructions that ordered Sterrett to disarm and release vessels Sterrett was able to conquer on the way to Malta, but that allowed Sterrett to seize such vessels on his way back from Malta. ${ }^{63}$ Sterrett met and defeated a fourteen-gun Tripolitan cruiser on his way to Malta and, acting in accordance with Dale's instructions, disarmed and released it. ${ }^{\text {it }}$

Jefferson had received a full report of Sterrett's victory by December 8 , 1801, when he delivered his first annual message to Congress. ${ }^{65}$ He reported

\footnotetext{
Jefferson failed to reveal that the letter had, in fact, been accompanied by another, "confidential" letter of the same date and a memorandum purporting to discuss the conspiracy, both of which would have been useful to Burr in undermining Wilkinson's credibility. These documents appear in $2 \mathrm{~J}$. Wilkinson, Memoirs of My Own Times app. xcy (1816). See discussion in 5 D. Malone, JefFerson and His Time. SeCond Term 1805-1809, at 248-49, 325 n.35 (1974).

60. See 1 Writings of Thomas Jefferson, supra note 58 , at $365-66$. The sole dissenter was Levi Lincoln.

61. See 1 Naval. Documents Related to the United States Wars With thf. Barbary Powers 465-67 (1939) [hereinafter cited as Naval Documents].

62. See, e.g., Orders from Richard Dale to Samuel Barron. July 4, 1801. in 1 Naval Documents 500, and July 9, 1801 , in $i d$. at 505; Orders from Richard Dale to Andrew Sterrett, July 5, 1801, in id. at 503, and July 30, 1801, in id. at 534-35.

63. Dale wrote Sterrett that he should return from Malta "as soon as possible" and "not chace out of your way particularly in going, as you have not much water on board." Id. at 534. Dale continued that if Sterrett fell in with a Tripolitan corsair on his way to Malta that he could manage, he should heave its guns overboard, cut its masts, and leave it just able to manage to get to port. If the encounter occurred on the way back from Malta, Sterrett was to "bring her with you if you think you can doe it with safety but on no account run any risque of your vessel or the health of your Crew." Id. at 535.

64. R. Irwin, The Diplomatic Relations of the United States With the Barbary Powers 109-10 (1931).

65. Sterrett had returned to Washington City, as it was then called, by November 17, with
} 
on Sterrett's encounter in a repeatedly quoted passage, attributing the release of the Tripolitan vessel to constitutional rather than tactical considerations: ${ }^{6} 6$

Unauthorized by the Constitution, without the sanction of Congress, to go beyond the line of defense, the vessel, being disabled from committing further hostilities, was liberated with its crew. The Legislature will doubtless consider whether, by authorizing measures of offence also, they will place our force on an equal footing with that of its adversaries. I communicate all material information on this subject, that, in the exercise of this important function confided by the Constitution to the Legislature exclusively, their judgment may form itself on a knowledge and consideration of every circumstance of weight.

Most commentators have accepted this famous statement of deference to Congress' power as accurate and made in goo'd faith. ${ }^{67}$ Actually, as we have seen, the cabinet had authorized offensive actions, and Dale had been instructed accordingly. Sterrett had released the corsair only because he was on his way to Malta, rather than on his way back, as he had been instructed by Dale. This fact would have been clear to Congress had Jefferson indeed communicated "all material information," as he said he would. By the time of his message, Sterrett had returned to the United States and had provided the full story of his encounter, including the true reasons he had released the corsair. ${ }^{68}$ This part of the story was withheld from Congress.

These facts undermine the importance so widely attributed to Jefferson's statement to Congress regarding Sterrett's conduct. But the orders issued to Dale, even as broadly construed, seem constitutionally defensible under even a relatively narrow view of executive power. One can reasonably infer from the power to defend against attacks on the United States-universally held to be granted by the framers-a power to act offensively against any nation that declared or made war. This was the view adopted by both Gallatin and Hamilton, and probably by Madison as well. ${ }^{69}$

We should well ask, therefore, why Jefferson suggested to Congress that he lacked authority to act offensively against a nation that had, in fact, both declared and made war on the United States.

Jefferson's message suggests an answer. He specifically asked for authority

dispatches and a report on the incident. See article from the National Intelligencer, reprinted in 1 Naval Documents 538-39, attributing Sterrett's release of the vessel to his sense of mercy.

66. 11 AnNals of Cong. 12 (1801).

67. See, e.g., C. Berdahl, The War Powers of the Executive in the United States 63 (1921); R. Berger, supra note 4, at 80; E. Corwin, supra note 4, at 131-33; 4 D. Malone, Jefferson the President: First Term, 1801-1805, at 98-99 (1970); Note, 81 Harv. L. Rev. 1771, 1779 (1968)

68. Jefferson sent Congress, after some delay, the instructions issued to Dale, and Sterrett's description of the encounter, but not the latter's orders from Dale. See 12 Annals of Cong. 701, 734-39 (1801).

69. See Letter from Albert Gallatin to Thomas Jefferson (Dec. 1802), in 1 Writings of Albert Gallatis 104-05 (H. Adams ed. 1960); 7 Works of Alexander Hamilton, supra note 27, at 746-47; I Writings of Thomas JefFerson, supra note 28, at 366. 
for "measures of offense," the granting of which he undoubtedly realized would enable him to dispatch expeditions such as Dale's without basing their legality on the mere fact that vessels of war had been constructed and placed within his power to utilize. ${ }^{\text {"I }}$ In this manner, he could also share with Congress responsibility for the increased intensity with which the war was to be conducted.

If Jefferson's description of Sterrett's conduct was intended to cause Congress to authorize offensive actions, he certainly succeeded. After meager debate, Congress adopted an act that gave explicit authority to the President to capture and make prizes of any Tripolitan vessel, and in sweeping terms "to cause to be done all such other acts of precaution or hostility as the state of war will justify, and may, in his opinion, require."71 Congress thereby continued, this time without recorded objection, the practice adopted during the Quasi War of authorizing hostilities without formally declaring war. And the authorization concerning Tripoli was surely as broad and as vague as the Gulf of Tonkin Resolution, passed after questionable executive representations in $1964 .^{72}$

It was not long before Jefferson used the power delegated to him by Congress to implement a plan that could not have been anticipated when the delegation was made. The plan has an eerie familiarity today. But in 1801, it was unprecedented. An elder brother of the Pasha of Tripoli, it seems, was willing to promise great concessions if the United States were to assist him in obtaining the throne. James L. Cathcart, American consul at Tripoli, suggested to Madison, in a letter dated July 2, 1801, the possibility of "dethroning the present Bashaw, and effecting a revolution in favor of his brother Hamet, who is at Tunis, and thereby insure the United States the gratitude of him and his successors." ${ }^{73}$ Implementation of the plan was delayed for over a year, because Hamet was temporarily reconciled with his brother. William Eaton, consul at Tunis, convinced Hamet to switch allegiances, however, and by August 1802 Madison was called upon to decide whether to allow the plan to go forward.

Madison noted in a letter to Cathcart how difficult it would be to judge and manage the project from so great a distance. He also added that "it does not accord with the general sentiments or view of the United States to intermeddle with the domestic controversies of other countries." But he could not

70. See 11 Annals of Cong. 12 (1801). The cruise was justified by the Secretary of the Navy to Dale under the law "providing for a Naval Peace Establishment," apparently on the assumption that at least a training exercise was implicity authorized by legislation merely providing the forces. See Act of Mar. 3, 1801, ch. 20, § 2, 2 Stat. 110; Order from Samuel Smith to Richard Dale (May 20, 1801), in 1 Naval. Documents 463, 465.

71. Act of Feb. 6, 1802, ch. 4, \& 2, 2 Stat. 129, 130.

72. See generally Joint Resolution of Aug. 10, 1964, Pub. L. No. 88-408, 78 Stat. 384.

73. 16 Annals of Cong. 704 (1807). 
resist the opportunity- "it cannot be unfair, in the prosecution of a just war, or the accomplishment of a reasonable peace, to take advantage of the hostile cooperation of others," he wrote. "As far, therefore, as the views of the brother may contribute to our success, the aid of them may be used for the purpose." He anticipated the possibility that Hamet's object might be unattainable, and stated that the honor of the United States and "the expectations he will have naturally formed" would require America "to treat his disappointment with much tenderness; and to restore him, as nearly as may be, to the situation from which he was drawn." "74 Hamet, in other words, was to be used for "our success," but, as Secretary of the Navy Smith ordered Commodore Morris on August 28, Hamet was not to be an obstacle to achieving an acceptable peace with Tripoli. ${ }^{75}$

After considerable delay, the plan was put into operation with full cabinet approval. ${ }^{\text {it }}$ Commodore Samuel Barron, in charge of the Mediterranean squadron, ordered Captain Isaac Hull in writing to take his vessel, the Argus, to Alexandria for refitting and other innocuous purposes. Actually, Hull's true orders were verbal, the written ones being "intended to disguise the real object of your expedition," said Barron, "which is to proceed with Mr. Eaton to Alexandria, in search of Hamet-and to convey him and his unit" to such "place on the coast as may be determined the most proper for cooperating with the naval force under my command." Hull was authorized to assure Hamet of Barron's "most effectual" cooperation "against the usurper" and in reestablishing Hamet as Pasha. ${ }^{i}$

The army Eaton and Hamet put together consisted of a handful of Americans, some Greek mercenaries, and about two thousand Arabs, with their women and children, all hired for the purpose. This motley conglomeration managed to conquer Derne, but Eaton reported that he had already spent $\$ 30,000$, or $\$ 10,000$ more than had been authorized by the administration. Eaton felt victory was certainly obtainable, but cautioned Barron that Hamet and his men lacked the ability, following, and resources to take Tripoli without further, substantial American military and fiscal support. ${ }^{78}$

Hamet's expedition apparently convinced his brother Joseph to seek peace, and Barron decided to dump Hamet in exchange for a favorable treaty." Eaton managed, however, to evacuate Hamet and his retinue, the

74. Letter from James Madison to James Cathcart (Aug. 22, 1802), in id. at 709.

75. Letter from Secretary of Navy Robert Smith to Commodore Richard Morris (Aug. 28, 1802), in R. Morris, A Defense of the Conduct of Commodore Morris During His Command in the MediterRaNeAN 45 (1804).

76. See I The Writings of Thomas Jefferson, supra note $\mathbf{5 8}$, at 382.

77. Letter from Samuel Barron to Isaac Hull (Sept. 13, 1804), and transcription of verbal orders of Barron to Hull (Sept. 15, 1804), in 16 AnNals of Cong. 713-14 (1807).

78. Letter from William Eaton to Samuel Barron (Apr. 29 and May 1, 1806) (extract and date in error), in id. at 731-34.

79. See R. IRwiN, supra note 64 , at $149-53$ 
Greeks and the Americans, in a scene that, as Eaton described it, brings to mind recent events at the United States consulate in Saigon: ${ }^{81}$

[A]ll the Constellation's boats were laid along side our wharf. I ordered the
Captain of cannoniers to embark his company with the field pieces and a ten
inch howitzer which fell into our hands on the 27 th of April; and after them
the Greek company. This was executed with silence and alacrity; but with
astonishment. The marines remained at their posts. When the boats were seen
returning I sent a messenger to the Bashaw requesting an interview. Under-
standing the purport of this message, he immediately repaired to the fort
with his retinue; dismounted, and embarked in the boats. The marines fol-
lowed with the American officers. When all were securely off, I stepped into a
small boat which I had retained for the purpose, and had just time to save my
distance when the shore, our camp, and the battery, were crowded with the
distracted soldiery and populace; some calling on the Bashaw; some on me;
some uttering shrieks; some execrations! Finding we were out of reach, they
fell upon our tents and horses. which were left standing; carried them off,
and prepared themselves for flight.

Eaton returned to America a hero, and was handsomely rewarded. Hamet applied to Jefferson for relief, basing his claim in part on an alleged commitment to place him on the throne. After considerable debate, Hamet received a small payment. ${ }^{81}$ No legislator questioned the legality or propriety of the joint action with Hamet. Everyone apparently assumed that the sweeping delegation, granted in response to Jefferson's report of Sterrett's encounter, extended to the plan to make Hamet the Pasha. The only significant complaint heard in Congress was that the President had reneged on his alliance with Hamet, not that he had made one. ${ }^{82}$

We can therefore say, in retrospect, that the doctrinal differences that separated Jefferson and his party from the Federalists failed to deter the former from exercising power in the same manner as a strong Federalist president, backed by a legislative majority. Vigorous, inventive leadership was part of Jefferson's nature. By 1807, he had arrived at a construction of the executive clause that amounted to a complete justification for adopting any measure necessary to accomplish a legitimate end: "[1]f means specified by an act are impracticable," he said, "the constitutional power to carry laws into execution remains, and supplies them." 83

We should hardly complain, however, that he largely ignored the constitutional straight-jacket he had inflicted upon himself. His achievements were substantial and of lasting value. But his doctrinal leanings may well have ac-

80. Letter from William Eaton to Commodore John Rodgers (June 13, 1805), in C. Prentiss, The Life of the Late General William Eaton 362-63 (1813).

81. R. IRwIN, supra note 64, at 160; 15 ANNals of CoNG. 1106 (1806) (bill authorizing payment to Hamet of $\$ 2,400$ ); id. at $185-88$ (report critical of abandoning Hamet).

82. 15 Anvals of Cong. 185, 187-88 (1806).

83. Letter from Thomas Jefferson to Gov. William H. Cabell (Aug. 11, 1807), in 10 THE Writings of ThOMAS JefFerson, supra note 58 , at $441 \mathrm{n}$. 
counted in part for the creation of new practices and claims that constitute a heritage of questionable value. Thus, instead of openly assuming and exercising a power to withhold material for public considerations, as Washington had done, Jefferson seems to have preferred to avoid potential doctrinal confrontations and legislative interference by simply keeping Congress-and in the Burr trial, a federal court-ignorant of information within his possession or control. And, instead of modifying Republican doctrine to legitimize his conduct after the Chesapeake affair, or the legislative absorption of the Louisiana Territory, ${ }^{84}$ he applied the doctrine of emergency power in a manner that allowed an escape from virtually all constitutional restraints. These new developments may have had little real importance in Jefferson's time, since most of his conduct could be rationalized under a more robust, but precedented, view of executive authority. Nothing prevented future Presidents, however, from using the powers developed by Jefferson in situations far less conventional than those in which he had invoked them.

Executive War Making, 1809-1812

The administrations of James Madison and James Monroe are even richer in material relating to war making than those of their predecessors. Close scrutiny of all that material is unnecessary in this presentation. These are famous Presidents, whose terms covered a period during which the United States grew and became stronger. Madison and Monroe properly reap the credit due them for the important developments that took place under their stewardship. We have lost much of the flavor of these men, however, in the adulatory descriptions with which most historians have provided us. A brief look at some of their activities in the Floridas should contribute to filling out our understanding of them as wielders of executive power.

\section{A. West Florida}

Jefferson had claimed that West Florida-roughly the area to the west of present-day Florida and to the east of Baton Rouge-had been transferred to the United States as part of the Louisiana Purchase. Congress authorized Jef-

84. In connection with his departure from his own scruples concerning the absorption of Louisiana, Jefferson said:

A strict observance of the written laws is doubtless one of the high duties of a good citizen, but is not the highest. The laws of necessity, of self preservation, of saving our country when in danger, are of higher obligation. To lose our country by a scrupulous adherence to written law, would be to lose the law itself, with life, liberty, property and all those who are enjoying them with us; thus absurdly sacrificing the end to the means. Letter from Thomas Jefferson to John B. Colvin (Sept. 20, 1810), in 9 Writings of Thomas JEFFERSON, supra note 28, at 279. See also id at 281. 
ferson, in general terms, to take possession of the area ceded by France. ${ }^{85}$ He was prepared at the time to seize at least parts of West Florida, if Spain refused to surrender New Orleans. ${ }^{86}$ Spain ceded New Orleans, however, and was left in control of the contested area. In 1804 Congress authorized Jefferson, when he deemed it expedient, to establish a customs district at Mobile, at the very heart of West Florida. ${ }^{87}$ Spain became acutely concerned, and Secretary of State Madison assured them that the act would be applied only within "the acknowledged limits of the United States," unless Spain itself agreed to cede the territory. ${ }^{88}$ Despite these conciliatory gestures, Jefferson was privately resolved to acquire not only West Florida but East Florida as well, "probably" Cuba, and apparently even Mexico. ${ }^{8.9}$

Soon after Madison became President, William Claiborne, Governor of the Orleans Territory, reported that West Florida was ripe for acquisition by the United States.9" During the summer of 1810, Claiborne travelled to the national capitol, apparently for discussions with Madison and Robert Smith, Secretary of State. From Washington, Claiborne wrote an extraordinarily important letter on June 14 to William Wykoff, Jr., a judge of the parish at West Baton Rouge, describing America's acquisition of West Florida as inevitable. He was "persuaded under present circumstances," however, that "it would be more pleasing that the taking possession of the Country, be preceded by a Request from the Inhabitants. -Can no means be devised to obtain such Request?" He told Wykoff that while "the most eligible means of obtaining an expression of the wish of the Inhabitants of Florida, can best be determined by themselves," it would be "more satisfactory" if done through the medium

85. Act of Oct. 31, 1803, ch. 1, 2 Stat. 245.

86. Jefferson had, in fact, prior to congressional passage of the authorizing Act of Oct. 31 , 1803 , ordered, by his Secretary of War, that preparedness measures be taken should any "serious opposition take place"; that in furtherance of this object "Boats, provisions, field Pieces, [etc. to be placed] in readiness; not only for regular Troops in the Terry but also for at least 500 of the best militia (who if necessary should be engaged for 3 months)." He did acknowledge that nothing could be done relating to the militia, "excepting the forming a system." Letter from Secretary of War Henry Dearborn to James Wilkinson (Oct. 5, 1803), in 9 Territorlal Papers of THE United States 71 (C. Carter ed. 1940). Orders were also sent to the commanding officer at Chickasaw Bluffs on the same date to be ready to move down, at the shortest notice. Id. at $7 \mathrm{l}$ n.86. Additional orders, of the same date as the authorizing act, instructed Wilkinson to take Baton Rouge, an area only disputably encompassed by the Louisiana Purchase, if he encountered opposition from Spain on his trip to New Orleans to take possession under the recent treaty. Letter from Secretary of War Henry Dearborn to James Wilkinson (Oct. 31, 1803), in id. at 97-98.

87. Act of Feb. 24, 1804, ch. 13, § 11, 2 Stat. $251,254$.

88. 4 I. Brant, James Madison 198 (1953).

89. See, e.g., Memorandum to Cabinet (Aug. 12, 1808), in 11 Writings of Thomas Jefferson, supra note 58, at 42-43; Letter from Thomas Jefferson to James Bowdoin, Minister to France, (Apr. 2, 1807), in 6 Bowdoin and Temple Papers 371-73 (66 Mass. Hist. Soc'y Coll., 7ih ser. 1907).

90. Letter from William Claiborne to Secretary of State Robert Smith (Mar, 19, 1809), in 4 Official Letter Books of W.C.C. Claiborne, 1801-1816, at 333 (D. Rowland ed. 1917). 
of a "Convention of Delegates," at which "every part of the District as far at least as the Perdido be represented." He urged Wykoff "to prepare for the occasion the minds of the more influential characters in the vicinity of Mobile," keeping "this letter as confidential."

The available evidence overwhelmingly proves that Claiborne's letter and plan were authorized by the President, as Claiborne himself reportedly claimed on June 20, in a letter to Governor David Holmes of the Mississippi Territory. ${ }^{92}$ Thus, also on June 20, Secretary of State Smith wrote to Wykoff, officially authorizing his mission. ${ }^{93}$ On July 17, Madison wrote Smith concerning a letter Smith had sent him from Governor Holmes. Madison said Holmes should be encouraged to continue his reports, and to keep his militia ready in case "of foreign interference with W.F. or of internal convulsions." He then concluded by asking Smith: "Will it not be advisable to apprize Gov. H. confidentially, of the course adopted as to W.F. and to have his co-operation in diffusing the impressions we wish to be made there?"44 Though no response from Smith to Madison has been found, Smith wrote again to Holmes on July 21, passing on Madison's instructions regarding the militia. In order that Holmes "be fully apprized of the course adopted as to the Floridas," Smith added, "and therefore the better able to co-operate in diffusing the impression we wish to make there, I deem it proper to send you the enclosed copy of instruction ... . and extracts of a letter from Governor Claiborne to Col. William Wykoff, written under a sanction from the President. . . The instructions contained in this letter are entirely confidential," he added, "and are to be executed in a manner the least calculated to incite alarm." ${ }^{95}$

Events proceeded in accordance with the administration's plan. The rebels called a convention with delegates from the entire area, adopted a constitution, declared their independence, and invited the United States to assume control. At that point, however, Madison realized that to accept the rebels' invitation would constitute an act of war against Spain, and would implicitly suggest an abandonment of America's claim to the area. He therefore issued a proclamation on October 27, 1810, declaring that events in West Florida had made it necessary that the United States exercise its right to the territory, and ordering Claiborne to assume control of certain areas. ${ }^{96}$ The proclamation recited that the area would be held subject to negotiations with Spain, but when Madison revealed its issuance to Congress, well over one month later, he urged that the territory be accepted into "the bosom of the American

91. 5id. at $31-33$.

92. See Padgett, The West Florida Revolution of 1810, 21 LA. Hist. Q. 177 n.227 (1938), reporting that Claiborne wrote Holmes that he had persuaded President Madison to accept his plan.

93. 9 Territorial Papers of the United States, supra note 86 , at 883-84.

94. 8 The Writings of James Madison 105-06 (G. Hunt ed. 1908).

95. Domestic LetTers of Dep't of State, Nat'l Archives microfilm, M-40, reel 13.

96. 1 Messages and Papers of the Presidents 465-66 (J. Richardson ed. 1897). 
family." ${ }^{97}$ Irving Brant correctly notes that, by keeping the proclamation secret until it had been implemented, Madison was able to present Spain, Britain, and France with a fait accompli. ${ }^{98}$ But one must add that he thereby presented the same accomplished fact to Congress as well.

The takeover of West Florida led to some interesting debates in Congress on its legality and propriety. Henry Clay termed it "propitious," and said that, had Madison failed to act, "he would have been criminally inattentive to the dearest interests of this country." predicted that, before the close of the session, a bill might well be introduced to take possession of East Florida as well. ${ }^{100}$ Clay hardly regarded this possibility as unwelcome, declaring his "hope to see, ere long, the new United States ... embracing not only the old thirteen States, but the entire country east of the Mississippi, including East Florida, and some of the territories to the north of us also."111

\section{B. East Florida}

Horsey's prediction was fulfilled sooner than even he expected. On January 3, 1811, Madison communicated "in confidence" letters from Vicente Folch, Spanish Governor of the Floridas, indicating Folch's conditional resolve to deliver "this province to the United States under an equitable capitulation." Madison recommended "a declaration that the United States could not see, without serious inquietude," the transfer of East Florida "from the hands of Spain into those of any other foreign Power." He also asked Congress to authorize him "to take temporary possession of any part or parts of the said territory," if voluntarily surrendered, and left it to "the wisdom of Congress" to determine "how far it may be expedient to provide for the event of a subversion of the Spanish authorities within the territory in question, and an apprehended occupancy thereof by any other foreign Power."1112

Madison's message made East rather than West Florida the chief subject of the Senate's further deliberations. He gave the impression by this message that he was treating East Florida very differently than he had treated West Florida. His actions in West Florida could be justified as based on a claim to that territory, whereas the United States had made no claim to East Florida.

In reality, and unknown to Congress, the administration had sought to bring about an internal upheaval in East Florida at the same time it did so in the western area. On the same day that Smith made Wykoff a special agent

97. 22 AnNals of Cong. 13 (1810).

98. 51. Brant, supra note 88 , at 189 . See also id. at 500-01, discussing Madison's failure to call back Congress earlier than scheduled.

99. 22 Annals of Cong. 62 (1810).

100. Id. at 45 .

101. Id. at 64 .

102. Id. at 125-52, 1259. 
for West Florida, he asked Senator William Crawford of Georgia to pick another agent to bring about the same result in East Florida. ${ }^{113}$ Crawford picked George Mathews, who actively pursued his task. With this background, we can appreciate more completely why Madison asked for authority to take East Florida in the event of internal "subversion."

Congress passed the declaration Madison sought, but did not authorize a takeover for internal subversion. The act passed did, however, allow a takeover of any territory surrendered by agreement of the "local authorities," a phrase significantly more general than the surrender from Spain that Madison had mentioned in his message. ${ }^{104}$

Once Congress acted, Madison formally appointed Mathews as commissioner to negotiate the capitulation of East Florida. Military personnel in the area were ordered to cooperate with him. ${ }^{115}$ When the Spanish finally refused to cede the area, Mathews sought to achieve his objective by encouraging a revolt. He reported on August 3, 1811 to Monroe, by then Secretary of State, that the inhabitants were ripe for revolt, but unable "to effect a thorough revolution without external aid." He suggested channeling arms to them from local American troops, and promised to "use the most discreet management to prevent the United States being committed."116 Monroe received Mathews' letter, but chose not to reply. Mathews then went ahead with his plan, and provided both arms and men to the so-called "patriots." He arranged to follow the patriots across West Florida, helping them take over each post, and then receiving the post from them as the "local authorities." Mathews apparently hoped thereby to comply with the letter of his instructions and with the law passed by Congress at Madison's request. ${ }^{107}$

The patriots took control of several posts, including Amelia Island, which they dutifully turned over to Mathews. But the refusal of a local American officer to cooperate prevented them from taking St. Augustine. At this point, in April 1812, the administration determined that Mathews was a liability and removed him. Monroe claimed that Mathews had exceeded his instructions, ${ }^{118}$ yet he picked the Governor of Georgia, David B. Mitchell, as Mathews' re-

103. Letter from Robert Smith to William Crawford (June 20, 1810), in Domestic LeTters of DeP'T of STATE, supra note 95, at M-40, reel 13. When Smith heard that Crawford had chosen Mathews, he wrote taking "great pleasure" in assuring Crawford that the President was "perfectly satisfied" with Crawford's choice; Mathews, he added, "well understanding the views of the executive, cannot but be happy in promoting them." Letter from Robert Smith to William Crawford (Oct. 2, 1810), in id.

104. Act of Jan. 15, 1811,3 Stat. 471.

105. Letters from Secretary of War William Eustis to Brigadier General Wade Hampton and Colonel Thomas cushing, respectively (Jan. 24, 1811), in LeTters Sent by Secretary of War Relating to Military Affairs (1800-1889), Nat'l Archives microfilm, M-6, reel 5.

106. Florida Territorial Papers of Dep't of State, Nat'l Archives microfilm, M-1 16, reel 1 .

107. J. Pratt, Expansionists of 1812, at 101 (3d ed. 1957).

108. Letter from James Monroe to George Mathews (Apr. 4, 1812), in 3 American STATE

Papers, Foreign Relations 572 (1832). 
placement. Mitchell was openly committed to the acquisition of East Florida, and reacted strongly to the suggestion in Monroe's instructions that the area taken by Mathews would have to be surrendered. ${ }^{109}$ Monroe in effect assured him that a withdrawal was not intended, since he made it conditional on a guarantee of the safety of the patriots. ${ }^{110}$ Colonel Ralph lsaacs, who carried messages between Monroe and Mathews, wrote to Monroe in July 1814 (as part of an application for payment) that "when you had finish'd your instructions to Gov'r. Mitchell after reading the 'sine qua non' that render'd the restoration of the Province utterly impracticable, you said to me-Gov'r. Mitchell will understand this wont he? to which I replied-he is not dull of comprehension Sir! . . . Nor can you forget," Isaacs added, "that at every interview I was assured that government were concerting (to use your own words) measures to keep the Province \& save harmless the Patriots." 11

In fact, Mitchell stayed in East Florida. Madison sought legislative approval of the occupation, but the Senate narrowly denied authority. ${ }^{112}$ Monroe was disappointed, but wrote to Mitchell that the earlier act still applied, and the occupation continued. ${ }^{113}$ The administration then decided to move in earnest to take over the entire area. General William Pinckney was appointed to replace Mitchell, and the local garrisons were reinforced for offensive action. ${ }^{114}$ Among the new units was one under the command of Andrew Jackson, who assured Monroe that his men had "no constitutional scruples," and were eager to take the province. ${ }^{15}$

Madison and Monroe sought once more to obtain Congress' approval to assume control of East Florida. Once again, the Senate balked, though they did authorize the take-over of Mobile, then in Spanish hands. ${ }^{116}$ Even after

109. Mitchell had written to Secretary of War William Eustis on April 20, 1812, urging the government to adopt a "prompt and decisive course" in East Florida, and pledging his state's zealous cooperation. J. Pratt, supra note 107, at 117-18. See his reaction to Monroe's letter of appointment (May 2, 1812), in Florida Territorial Papers, supra note 106, at M-116, reel 2.

110. He made explicit his earlier suggestion that Mitchell was not to withdraw the troops "unless you find that it may be done consistenty with their safety." Letter from James Monroe to David Mitchell (May 27, 1812), in 3 American STATe PAPERS, supra note 108, at 573.

111. Letter from Ralph Isaacs to James Monroe (July 3, 1814), in Misc. LetTers of Dep't of State, Nat'l Archives microfilm, M-179, reel 30.

112. The bill was defeated in the Senate, fourteen to sixteen. 23 Annals of Cong. 326 (1812).

113. The "authority of the Executive remains unchanged," he said. He continued that the President thought it "most advisable" that the troops be withdrawn, but added conditions and said that the administration would probably ask Congress for authority to take possession in the next session. Letter from James Monroe to David Mitchell (July 6, 1812), in 9 STATE PAPERS AND Publick Documents of THE U.S. 161-64 (T. Wait ed. 1817). Mitchell replied that various circumstances made it impossible to withdraw the troops, and Monroe did not answer. Letter from David Mitchell to James Monroe (July 17, 1812), in id. at 164-65.

114. Letter from James Monroe to Thomas Pinckney (Dec. 8, 1812), in id. at 188-91: Letter from William Eustis, Secretary of War to Thomas Pinckney (Dec. 2, 1812), in J. Pratr, supra note 107 , at $211,217$.

115. 1 J. Parton, The Life of Andrew Jackson 372 (1860).

116. The vote was nineteen to sixteen against authorizing the President to take possession of 
this further rejection of administration policy, Monroe would have preferred at least to hold the territory acquired by Mathews. The issue became part of the negotiations to settle the War of 1812, however, and Madison finally ordered a withdrawal at the insistence of the American negotiators. ${ }^{117}$

Much more remains to be said about executive war making, especially under Monroe. The full story of each adventure is unnecessary for present purposes. In general, though, it can be said that the early Presidents continued aggressively and secretly to work to acquire territory in the South and West. The great negotiated acquisition of the Adams-On is Treaty was largely the product of pressure placed upon Spain through the legislatively unauthorized Seminole War. ${ }^{118}$

\section{Conchusion}

The presidency was powerful, in a very modern sense, by the end of George Washington's administration. During those eight years, many of the practices we associate with executive power generally, and more particularly in foreign affairs, were established, and with a high degree of awareness as to the potential consequences. By 1800 , John Adams had intentionally led the nation into its first major war without seeking a formal declaration. Jefferson and the Republicans promised change, a return to proper principles and legislative government. Actually, they expanded executive power, systematized secrecy in government, and expounded the notion that emergencies justify departures from the Constitution. They also succeeded in obtaining the earliest analogue to the Gulf of Tonkin Resolution, and used it as authority for the nation's first effort to subvert a foreign government from within. Under Madison, these powers and practices coalesced so that the administration proceeded secretly and unilaterally to plot and support revolutions in West and East Florida, and in effect to make war without prior legislative approval.

One is naturally led by all these facts to ask whether anything has changed since those early times. Despite the strength and independence of our early Presidents, the answer is definitely yes. Perhaps the most obvious difference is in rhetoric. Our first Presidents were overtly deferential to Congress, whereas more recent Chief Executives have been condescending or challenging at best. More significantly, our early Presidents at no time asserted at least two claims heard frequently of late. The first is that the President may use whatever raw power he has-monetary, diplomatic and military-in the national interest. Even Jefferson's rationale for escaping the Constitution required an

East Florida. 25 Anvals of CoNG. 130 (1813). The bill authorizing possession of Mobile passed within days. Id. at 132 .

117. See J. Pratr, supra note 107, at 236.

118. This point is generally supported in S. Bemis, Johx Quincr Adams and THE Foundations of American Foreign Policy 313-16 (1956). See also the specific suggestion that territory taken be retained to help in later bargaining with Spain. 4 Memoirs of JoHx Quincy Adams 35-36 (C. Adams ed. 1875); W. Cresson, James Monroe 297-99 (1946). 
emergency. The second is that the President's so-called inherent powers as Chief Executive and Commander in Chief do not merely authorize actions in the absence of legislative directions, but are beyond legislative control. No early President suggested that Congress was significantly limited in the control it potentially had over assigned executive powers. The Supreme Court, in fact, upheld the legality of undeclared war because Congress had chosen to proceed in that manner, not because of any executive power. Furthermore, the Court specifically declared that Congress could control the conduct of war even to a high degree, and that when it did so the executive acted unlawfully if it exceeded the legislature's limits. ${ }^{119}$ In the area of executive privilege, by analogy, though early Presidents claimed authority to withhold information, they never asserted that Congress lacked constitutional power to use whatever means at its disposal to compel production of the information involved, or to punish for its nonproduction.

Another, more substantive, difference is found in the conduct of our early Presidents. In questioning the hypothesis that the framers deferred to legislative power, I have stressed their initiatives and the least deferential aspects of their conduct. The full picture contains very substantial evidence of their concern for both the legislative and the popular will. Washington implemented neutrality, for example, with great caution, to appear evenhanded in treating Britain and France. ${ }^{20}$ Adams avoided a declaration of war, but sought legislative authority at each stage in the nation's movement toward war with France. Jefferson conducted diplomacy with vigor and secrecy, but moved conservatively in military matters, even when he could have claimed that Congress had approved a full-scale military effort to take West Florida. Madison and Monroe defy simplification; but it can be said of their adventures in the Floridas that they were pursuing popular objectives with minimal commitment of material and military resources. Their efforts cannot be equated with the unpopular, massive engagements in Korea and Vietnam. Furthermore, the fact that they acted in secret strongly suggests that they regarded their own activities as constitutionally questionable if not improper, and deprives those activities of the precedential weight they might have had if fully revealed to Congress.

Despite the vigor and initiative of the early Presidents, a case can therefore be made for the constitutional impropriety of at least some aspects of recent presidential rhetoric and conduct. But the nation's history suggests that

119. The two most important cases are Little v. Barreme, 6 U.S. (2 Cranch.) 170 (1804); and Brown v. United States, 12 U.S. (8 Cranch.) 110 (1814), discussed in L. HevkIN, supra note 10, at 96.

120. An excellent instance of Washington's conduct is his decision to adopt a nautical boundary for the United States that all nations had accepted. In this way, he avoided controversy, and left it for Congress to go further. See 6 Writings of Thomas Jefrerson, supra note 28, at 440-41. He said in his message to Congress when they reconvened that they, in effect, had the final say on neutrality and the system he had begun to implement. 4 Anvals of Cong. 10, 11 (1793). 
the price of pressing this case too far may be great. The presidency has served as the focal point of this nation's aspirations. What Samuel Huntington said of the twentieth century is no less true of the first forty years: "[W]henever the American political system has moved systematically with respect to public policy, the direction and the initiative have come from the White House." 121 The notion that Congress should become more involved in making and implementing foreign policy is unassailable in theory. But Congress has consciously chosen other roles for itself, and may continue to do so. To enable Congress to increase its foreign policy role significantly would require fundamental revisions in the legislature's decision-making apparatus, as well as in the attitudes of individual legislators. ${ }^{122}$ In short, without executive leadership we may have no leadership at all.

We can, of course, take this analysis one step further. So what if we lack "secrecy, despatch, and decision" in foreign affairs? These characteristics may have been confidently advanced as crucial to an effective executive in $1787,{ }^{123}$ but they remind many Americans today that our recent Presidents have been duplicitous, rash, and dogmatic. An allocation of governmental authority that facilitated geographic acquisitions and international respect between 1789 and 1829, despite our relative weakness, may be outmoded in an era when the costs of international influence by compulsion have become horrendous and when we are in danger of seeming brutish rather than weak. Our principal contribution to the world today may, as Daniel Bell suggests, be the very constitutionalism that prevents excess in a world that no longer can afford it. ${ }^{124}$

We no longer need a presidency capable of implementing a foreign policy based on "manifest destiny" or other outmoded notions. But so long as we have the power to defend ourselves, or an ally, or a principle, we bear the responsibility of deciding whether and how to do so. While Congress must be involved in these decisions, the executive will play an indispensable role in planning and implementing them until the very structure of American government is changed. Determining the proper extent of the President's role in this process is the truly difficult question. And we avoid both the question and its possible answers when we attribute the evils produced by our recent Presidents and Congresses to the violation of imagined norms allegedly established by the leaders of our constitutional period.

121. Huntington, The Democratic Distemper, 41 PuB. INTERest 9, 24 (Fall 1975). Huntington adds: "Probably no development of the 1960's and 1970's has greater import for the future of American politics than the decline in the authority, status, influence, and effectiveness of the Presidency." See also R. Nisbet, Twilight of Authority (1975).

122. See generally Symposium, Organizing the Government to Conduct Foreign Policy: The Constitutional Questions, 6I VA. L. Rev. 747 (1975); D. Mayhew, Congress: The Electoral Connection (1974).

123. 4 Debates in the Several State Conventions on Adoption of the Federal Constitutiox 107-08 (J. Elliot ed. 186I); The. Federalist No. 64, at 392-93 (C. Rossiter ed. 1961) (J. Jay): id. No. 75 , at 452 (A. Hamilton).

124. Bell, The End of American Exceptionalism, 41 PUB. INTEREST 193, 220-22 (Fall 1975). 